\title{
POPULATION SKILLS AS AN INDICATOR OF EUROPEAN COUNTRIES' COMPETITIVENESS IN THE MODERN ECONOMY
}

\author{
Vladimir Radivojević \\ Republic of Serbia, Ministry of Defense, Regional Centre Niš \\ Ernad Kahrović \\ State University of Novi Pazar, Department of Economic Sciences \\ Miloš Krstić \\ University of Niš, Faculty of Science and Mathematics
}

uman capital and population skills are the main drivers of economic growth and national competitiveness in the modern economy. The paper investigates the current state and development potential of selected European countries in the field of population skillscompetitiveness. Particular attention is paid to this issue in relation to the Balkan countries. The aim is to identify the factors of population skills that are critical for competitiveness of the Balkan countries and which have to be improved in the future. The analysis is based on the data published by the World Economic Forum in „The Global Competitiveness Report 2018“. The research has been done by applying the comparative analysis and benchmarking method. The research findings indicate that the level of population skillscompetitiveness of the Balkan countries lags significantly behind the top European countries. This study contributes to the skills and human capital literature and it could have practical implications in formulating the development policy of population skills in European countries.

Key Words: skills, human capital, competitiveness, Balkan countries, European countries

\section{Introduction}

The he term "skills" is used in the relevant literature to indicate what a person knows, understands, and can do. Consequently, skills are an important indicator of human capital quality. Starting from the assumption that the competitiveness and strategic development of national economies depend to a large extent on the quality of their human resources, the continuous investment in the formal education system and training programs of population has become an indispensable prerequisite for development in the contemporary business environment. Highly educated and skilled populations are more 
productive in the market because they have greater collective ability to perform tasks and transfer knowledge quickly, and also to create new knowledge in the era of the fourth industrial revolution (The World Economic Forum, 2018). Therefore, only "lifelong learning" provides a competitive position in the modern labour market.

The European Union (EU) members recognized the need to invest in human capital long time ago, which has enabled some countries from this group to become leaders in global terms. The European Commission Initiative termed "Investment in human capital" (2017) stated that "human capital is essential for boosting productivity, pivotal for economic growth and also vital with regard to the resilience of economies" (p. 1). This clearly indicates the importance and role of human capital in the economic development and national welfare of the EU countries. For example, the European Social Fund and the European Regional Development Fund alone will inject over $€ 30$ billion to support skills development in the period 2014-2020, and the Erasmus+ program supports skills development in education and training with nearly $€ 15$ billion (The European Commission, 2016).

Despite the respectable results that some EU countries achieve in terms of population skills, it is far from the fact that all EU countries are at the same level of development. It is quite expected that the level of population skills development varies from country to country in the EU region. Particularly, large differences in the level of development could be expected if other European countries (non-EU members) are included in the analysis. The European countries represent a heterogeneous group with very different results in various segments of national economy competitiveness. It is quite understandable since the mentioned countries are on the different stages of economic and social development.

The objective of this paper is to estimate the level of the European countries competitiveness in the field of population skills. The purpose is to measure the extent to which the Balkan countries lag behind the top-ranked European countries in terms of population skills, and also to identify the indicators of population skills that are critical for the Balkan countries competitiveness and which have to be improved in the future. The research is appropriate for all those who influence the formulation and implementation of formal education and training programs in the European countries, especially in the Balkan countries.

Theoretical background and literature review are considered in the first section of the paper. Research methodology and hypothesis are explained in the second section. The third part of the paper presents research results and discussions. The final section contributes conclusions.

\section{Theoretical background and literature review}

The conditions for participation and survival of companies in a modern global market have become more and more complicated in recent years. Some researches (Narula \& Dunning, 2000; Bevan \& Estrin, 2004; Bevan, Estrin \& Meyer, 2004) consider that the revolution in information and communications technology has led to the shifting of business activities from the resource-based towards capital-intensive economic sector. Technological revolution brings fundamental changes in the organization and structure of companies and industries, and also in the factory layout and the management structure, procedures, and attitudes of large companies (Singh, 1994). Rapid changes and con- 
stant adjustments to the business environment have become preconditions for success. The ability of any market participant to adopt and implement a new idea or to redefine its business concept depends onworkers' skills. This is the cause of unconditional acceptance of the philosophy of continuous education and lifelong learning, not only in the general context of society, but also every organization and individual.

Numerous theoretical and empirical studies point to the influence of human capital on economic development (Barro \& Lee, 2001; Dunning \& Lundan, 2008; Krstić, 2014; Jovanović, Nešković \& Kostić, 2016; Rađenović \& Krstić, 2017). Herciu \& Ogrean (2015) identify strong correlations between national wealth, national competitiveness, and national intellectual capital based on data from 40 countries. The paper of Bhattacharya, Gibson, \& Doty (2005) analyses the components of human capital flexibility and their potential relationship to firm performance. This study confirms that flexibility of employee skills, employee behaviors, and human capital practices represent critical factors of human resource flexibility and they are related to superior firm performance. The research conducted by Kottaridi, Louloudi \& Karkalakos (2019) estimate the role of human capital, skills, and competencies in the location of inward FDI by comparing Western, Central and Eastern EU members. The results of this study indicate "a major difference regarding theoretical and vocational education programs for both sub-regions; in addition, a major difference is obtained for particular qualifications in international scores". Doppelt (2019) regards that the economy grows endogenously as agents accumulate human capital in the long run.

The importance of human capital and population skills is highlighted in many studies as significant factor of creating comparative advantages of nations (Wright, McMahan \& McWilliams, 1994; Baldacci et al., 2008; Suri et al., 2011; Sverdlova, 2014). Under the constant influence of political, cultural, and economic changes at the local and global level, every national economy and its business micro-institutions should develop their comparative advantages if they would like to maintain and strengthen their competitive position in the market (Plantić, 2005; Krstić, Radivojević \& Stanišić, 2016; Radivojević, Krstić \& Stanišić, 2018). Improving the quality of human capital and population skills is a complex process that requires long-term, thorough planning, and coordinated action of diverse sections of the national economy.

The European Union has adopted several strategic frameworks and initiatives related to the improvement of education and population skills. For example, the strategic framework for "European cooperation in education and training" is a forum that allows the EU member states to cooperate in building best practice, and it has the following four common objectives (The European Commission, ET2020 framework): (1) make lifelong learning and mobility a reality; (2) improve the quality and efficiency of education and training; (3) promote equity, social cohesion, and active citizenship; and (4) enhance creativity and innovation including entrepreneurship at all levels of education and training. Furthermore, according to the European Commission (2016) the initiative termed "New Skills Agenda for Europe" was "number one in the list of major initiatives in the Commission Work Programme 2016" (p. 3). This initiative indicates the strategic importance of skills for sustaining jobs, growth, and competitiveness in the EU member states. Its main goals were: improving the quality and relevance of skills formation, making skills and qualifications more visible and comparable, and improving skills intelligence and information for better career choices. 


\section{Research methods and data basis}

The purpose of this research is to analyze the indicators of the European countries' competitiveness in terms of population skills. The data basis for the research consists of the secondary data published by the World Economic Forum in "The Global Competitiveness Report 2018". The methodology used by the World Economic Forum is based on measuring "Global Competitiveness Index" that combines 98 indicators of competitiveness, which are grouped in 12 pillars (see Figure 1). The score of pillars and indicators range between 0 and 100 . The highest score of 100 corresponds to the goal post for each indicator and typically represents a policy target for each country.

\begin{tabular}{ll} 
Enabling Environment \\
\hline Instiltutions \\
\hline Pillar 2 \\
Infrastructure
\end{tabular}

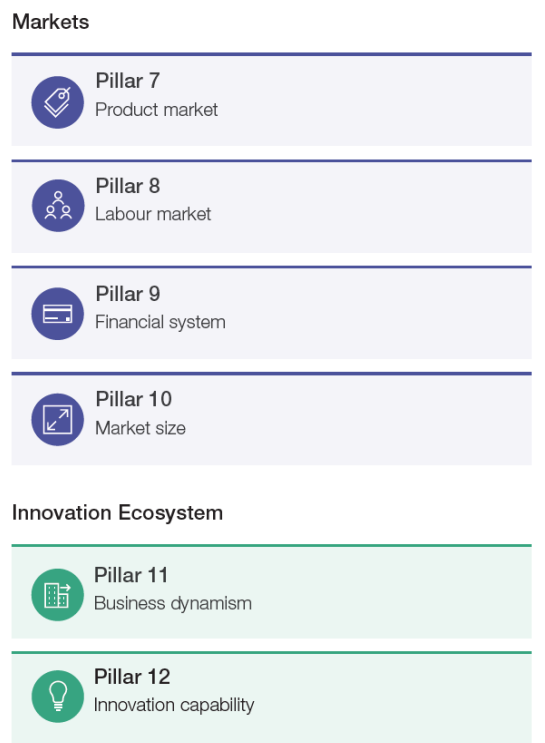

Figure 1 - The conceptual framework for measuring the Global Competitiveness Index (Source: The World Economic Forum, The Global Competitiveness Report, 2018, p. 39)

One of the 12 pillars in the Global Competitiveness Index that belongs to the group of "Human Capital" is "Skills" (Figure 1). According to the World Economic Forum (2018, p. 41), the Skills pillar captures the general level of workforce skills and the quantity and quality of education, whereby it is assumed that "while the concept of educational quality is constantly evolving, important quality factors today include: developing digital literacy, interpersonal skills, and the ability to think critically and creatively".

The Skills pillar is the $6^{\text {th }}$ pillar of the Global Competitiveness Index, and it consists of the following nine indicators:

1) Mean years of schooling;

2) Extent of staff training;

3) Quality of vocational training;

4) Skill set of graduates; 
5) Digital skills among population;

6) Ease of finding skilled employees;

7) School life expectancy;

8) Critical thinking in teaching; and

9) Pupil-to-teacher ratio in primary education.

The research has been conducted through benchmarking and the results of the Skills pillar of 10 Balkan countries are with the top 10 European countries. The following ten Balkan countries are included in the analysis: Albania, Bosnia and Herzegovina, Bulgaria, Croatia, Greece, Montenegro, North Macedonia, Romania, Serbia, and Slovenia. A benchmark group of countries consists of the following 10 European countries that have achieved the best scores in the Skills pillar: Denmark, Finland, Germany, Iceland, Ireland, Netherlands, Norway, Sweden, Switzerland, and the United Kingdom. The research has been conducted through comparative analysis and benchmarking method.

\section{Results and discussions}

\section{Analysis of skills competitiveness of top 10 European countries}

With the ambition to evaluate the skills competitiveness of the Balkan countries, it is applicable to identify the competitive position of the top 10 European countries with the highest score of the Skills pillar. This is important because the top 10 European countries would be a benchmark group of countries, which serves for comparison of the Balkan countries.

The World Economic Forum (2018) analyzed the performance of 140 national economies. Table 1 shows the position of the top 10 European countries, according to score and rank of the Skills pillar.

Table 1 - The score and rank of the top 10 European countries in the Skills pillar (2018)

\begin{tabular}{|c|c|c|c|c|c|c|c|c|c|c|c|}
\hline Indicators & 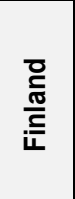 & 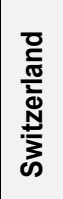 & 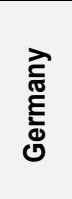 & 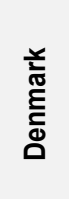 & 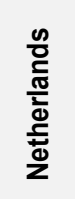 & 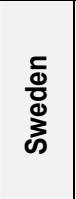 & $\begin{array}{l}\text { i } \\
\text { in } \\
\text { o }\end{array}$ & 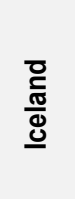 & 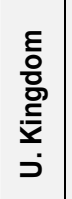 & 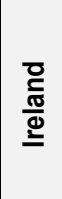 & 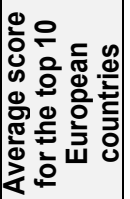 \\
\hline $\mathrm{I}_{1} \mathrm{Mear}$ & 94.7 & 91.5 & 93.8 & 82.8 & 80.9 & 82.3 & 85.2 & 83.3 & 84.6 & 83.3 & 86.24 \\
\hline staff training & 70.5 & 80.9 & 69.9 & 71.3 & 72.6 & 72.0 & 68.2 & 65.8 & 63.4 & 67.0 & 70.16 \\
\hline $\mathrm{I}_{3}$ Quality of vocational training & 73.4 & 92.3 & 73.1 & 74.2 & 75.7 & 66.6 & 69.8 & 67.9 & 62.0 & 64.7 & 71.97 \\
\hline $\mathrm{I}_{4}$ Skill set of graduates & 73.8 & 83.3 & 71.8 & 69.1 & 75.0 & 71.1 & 66.1 & 71.6 & 63.7 & 68.5 & 71.40 \\
\hline${ }_{5}$ Digital skills among population & 80.3 & 77.5 & 70.4 & 72.4 & 78.9 & 80.6 & 71.6 & 78.9 & 65.5 & 70.0 & 74.61 \\
\hline $\begin{array}{l}\mathrm{I}_{6} \text { Ease of finding skilled } \\
\text { employees }\end{array}$ & 72.3 & 70.1 & 70.1 & 64.3 & 66.6 & 66.2 & 70.6 & 66.2 & 69.2 & 67.4 & 68.30 \\
\hline $\mathrm{I}_{7}$ School life expectancy & 100.0 & 90.0 & 94.2 & 100.0 & 100.0 & 100.0 & 99.2 & 100.0 & 96.9 & 100.0 & 98.03 \\
\hline $\mathrm{I}_{8}$ Critical thinking in teaching & 73.8 & 73.9 & 70.7 & 75.2 & 70.9 & 72.0 & 64.0 & 60.2 & 67.6 & 52.6 & 68.09 \\
\hline $\begin{array}{l}\text { IPPupil-to-teacher ratio in } \\
\text { primary education }\end{array}$ & 91.7 & 99.7 & 94.4 & 98.2 & 95.7 & 94.8 & 100.0 & 99.6 & 81.5 & 84.8 & 94.04 \\
\hline \multirow{2}{*}{ Skills pilla } & 87.9 & 87.3 & 85.4 & 84.9 & 84.5 & 84.2 & 83.9 & 83.3 & 80.2 & 79.9 & 84.15 \\
\hline & 1 & 2 & 4 & 5 & 6 & 7 & 8 & 9 & 13 & 15 & - \\
\hline
\end{tabular}

(Source: The World Economic Forum, The Global Competitiveness Report, 2018) 
With eight countries in the world's top 10, Europe is an absolute leader in population skills competitiveness in global terms (see Table 1). Finland records the highest skills score among 140 countries (87.9). There are a lot of empirical studies which confirm that Finland has the best education system in the world. This is supported by the fact that the students from Finland have showed high academic achievement in international studies such as the OECD Programme for International Student Assessment (PISA) (Green, Preston \& Sabates, 2003; Savolainen, 2009; Schleicher, 2009; Bulle, 2011; OECD, 2011; Yada, Tolvanen \& Savolainen, 2018).

Finland is followed by the second-ranked Switzerland (87.3), and the third-ranked Germany (85.4). The first three European countries are followed by Denmark, Netherlands, Sweden, Norway, Iceland, United Kingdom, and Ireland. The average score of the top 10 European countries in the Skills pillar is 84.15.

Table 1 indicates that Finland records the best score in $I_{1}$ (Mean years of schooling) and $I_{6}$ (Ease of finding skilled employees); Switzerland is the best-ranked in $I_{2}$ (Extent of staff training), $I_{3}$ (Quality of vocational training), and $I_{4}$ (Skill set of graduates); Sweden in $I_{5}$ (Digital skills among population); Denmark in $I_{8}$ (Critical thinking in teaching); Norway in $\mathrm{I}_{9}$ (Pupil-to-teacher ratio in primary education); while 6 European countries achieved the maximum score of 100 in $I_{7}$ (School life expectancy).

\section{Comparative analysis of skills competitiveness determinants within the Balkan group of countries}

In order to analyze the results of the Balkan countries in terms of population skills, Table 2 presents the scores of each nine indicators of the Skills pillar for all Balkan countries. The data shown in columns 12 to 15 in Table 2 provides comparative analysis of average scores between the Balkan countries and the top 10 European countries, and also the best-scored country of each of these two groups in every indicator of the Skills pillar.

Table 2 - The score of indicators within the Skills pillar of the Balkan countries (2018)

\begin{tabular}{|c|c|c|c|c|c|c|c|c|c|c|c|c|c|c|}
\hline 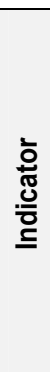 & $\begin{array}{l}\frac{\pi}{\frac{\pi}{5}} \\
\frac{0}{\omega} \\
\frac{\partial}{\omega}\end{array}$ & 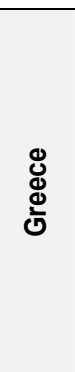 & 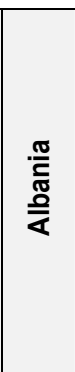 & 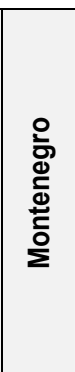 & $\begin{array}{l}\frac{\pi}{\frac{0}{0}} \\
\frac{0}{0} \\
\text { க) }\end{array}$ & $\begin{array}{l}\frac{\frac{\pi}{2}}{\mathrm{~d}} \\
\frac{\mathrm{J}}{\bar{\Xi}}\end{array}$ & 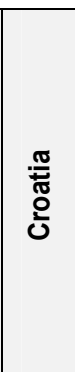 & 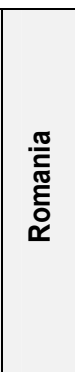 & 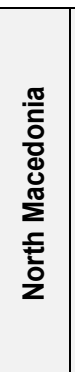 & 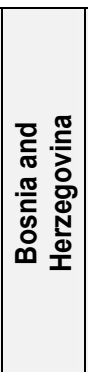 & 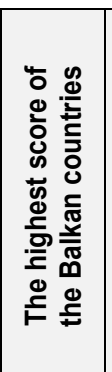 & 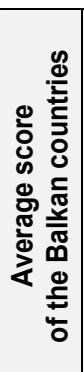 & 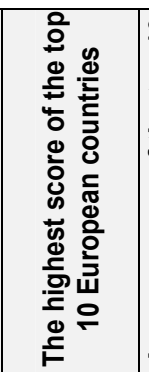 & 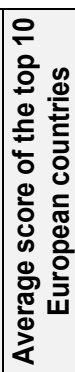 \\
\hline 1 & 2 & 3 & 4 & 5 & 6 & 7 & 0 & $y$ & 10 & 11 & 12 & 13 & 14 & 15 \\
\hline $\mathrm{l}_{1}$ & $82.5^{\star}$ & 71.6 & 68.0 & $74.7^{*}$ & $73.4^{*}$ & $73.3^{*}$ & $74.7^{*}$ & $73.3^{*}$ & 65.3 & 60.0 & \begin{tabular}{|c|}
82.5 \\
Slovenia
\end{tabular} & 71.6 & $\begin{array}{c}94.7 \\
\text { Finland }\end{array}$ & 86.2 \\
\hline $\mathrm{I}_{2}$ & $55.1^{*}$ & $43.5^{*}$ & $49.5^{*}$ & $9^{*}$ & $2^{*}$ & 40.1 & 34.7 & 40.0 & 33.2 & 33.8 & \begin{tabular}{|c|}
55.1 \\
Slovenia \\
\end{tabular} & 42.1 & \begin{tabular}{|c|}
80.9 \\
Switzerland \\
\end{tabular} & 70.2 \\
\hline$I_{3}$ & $52.7^{*}$ & 41.5 & $49.1^{*}$ & $48.8^{*}$ & $48.3^{*}$ & 44.1 & 41.4 & $48.4^{*}$ & 35.3 & 35.7 & \begin{tabular}{c|}
52.7 \\
Slovenia
\end{tabular} & 44.5 & \begin{tabular}{|c|}
92.3 \\
Switzerland
\end{tabular} & 72.0 \\
\hline
\end{tabular}


Population Skills as an Indicator of European Countries' Competitiveness in the Modern Economy

\begin{tabular}{|c|c|c|c|c|c|c|c|c|c|c|c|c|c|c|}
\hline$I_{4}$ & $55.7^{*}$ & $56.0^{*}$ & $53.4^{*}$ & $48.7^{*}$ & $53.9^{*}$ & 43.8 & 41.1 & 37.8 & 41.4 & 36.0 & $\begin{array}{c}56.0 \\
\text { Greece }\end{array}$ & 46.8 & $\begin{array}{c}83.3 \\
\text { Switzerland }\end{array}$ & 71.4 \\
\hline$I_{5}$ & $63.9^{*}$ & $53.3^{*}$ & $61.2^{*}$ & 52.3 & 52.7 & $54.0^{*}$ & 43.5 & $57.2^{*}$ & 43.6 & 47.1 & $\begin{array}{c}63.9 \\
\text { Slovenia }\end{array}$ & 52.9 & $\begin{array}{c}80.6 \\
\text { Sweden }\end{array}$ & 74.6 \\
\hline$I_{6}$ & $54.4^{*}$ & $56.6^{*}$ & $50.5^{*}$ & $49.3^{*}$ & $51.7^{*}$ & 39.1 & 38.7 & 37.3 & 38.2 & 38.1 & $\begin{array}{c}56.6 \\
\text { Greece }\end{array}$ & 45.4 & $\begin{array}{c}72.3 \\
\text { Finland }\end{array}$ & 68.3 \\
\hline$I_{7}$ & $95.6^{*}$ & $95.9^{*}$ & $85.4^{*}$ & 82.8 & 81.3 & 82.3 & 83.1 & 79.3 & 74.0 & 78.9 & $\begin{array}{c}95.9 \\
\text { Greece }\end{array}$ & 83.9 & $\begin{array}{c}100.0 \\
6 \text { countries }\end{array}$ & 98.0 \\
\hline$I_{8}$ & $36.0^{*}$ & 27.7 & $58.0^{*}$ & $44.5^{*}$ & $41.8^{*}$ & $37.0^{*}$ & 21.4 & 24.7 & 27.5 & 24.5 & $\begin{array}{c}58.0 \\
\text { Albania }\end{array}$ & 34.3 & $\begin{array}{c}75.2 \\
\text { Denmark }\end{array}$ & 68.1 \\
\hline$I_{9}$ & 82.7 & $100.0^{\#}$ & 79.5 & $86.6^{*}$ & $88.7^{*}$ & 81.0 & $90.7^{*}$ & 76.7 & $89.0^{*}$ & 81.8 & $\begin{array}{c}100.0 \\
\text { Greece }\end{array}$ & 85.7 & $\begin{array}{c}100.0 \\
\text { Norway }\end{array}$ & 94.0 \\
\hline Skills & $\mathbf{7 3 . 5}$ & $\mathbf{7 0 . 4}$ & $\mathbf{6 8 . 7}$ & $\mathbf{6 8 . 1}$ & $\mathbf{6 7 . 5}$ & $\mathbf{6 4 . 7}$ & $\mathbf{6 3 . 4}$ & $\mathbf{6 1 . 8}$ & $\mathbf{5 9 . 0}$ & $\mathbf{5 7 . 5}$ & - & - & - & - \\
\hline & $\mathbf{2 9}$ & $\mathbf{3 9}$ & $\mathbf{4 7}$ & $\mathbf{5 2}$ & $\mathbf{5 6}$ & $\mathbf{6 0}$ & $\mathbf{6 5}$ & $\mathbf{6 9}$ & $\mathbf{8 1}$ & $\mathbf{8 7}$ & - & - & - & - \\
\hline
\end{tabular}

(Source: The World Economic Forum, The Global Competitiveness Report, 2018)

Legend:

$\square$ Indicates that the score is below the average score of the Balkan countries.

$\square$ * Indicates that the score is above the average score of the Balkan countries.

$\square$ \# Indicates that the score is above the average score of the top 10 European countries.

The best-ranked Balkan country according to the score of the Skills pillar is Slovenia that reached the score of 73.5 and $29^{\text {th }}$ place in the world (see Table 2). The secondranked is Greece with the score of 70.4 , while the third-ranked is Albania with the score of 68.7. The first three Balkan countries are followed by Montenegro, Serbia, Bulgaria, Croatia, Romania, North Macedonia, and Bosnia and Herzegovina. Slovenia achieved the highest score in four indicators of the Skills pillar (Mean years of schooling, Extent of staff training, Quality of vocational training, and Digital skills among population); Greece in the other four indicators (Skill set of graduates, Ease of finding skilled employees, School life expectancy, and Pupil-to-teacher ratio in primary education); and Albania in Critical thinking in teaching indicator.

Bosnia and Herzegovina is the worst-ranked country in terms of skills competitiveness in the Balkan group. This country achieved the score of 57.5 and $87^{\text {th }}$ place in the global ranking. Also, the scores of all nine indicators in the Skills pillar in the case of Bosnia and Herzegovina are below the average score of the Balkan countries, which points to the fact that there are great disparities within the Balkan group when it comes to the results achieved in the skills competitiveness. Namely, the worst-ranked country in the Balkan group (Bosnia and Herzegovina) lags behind the best-ranked country (Slovenia) for even 58 places (the difference in achieved score is even 16.0).

The data presented in Table 2 demonstrates the great superiority of the European countries over the Balkan countries in the field of population skills. The comparison of the results presented in column 13 and 15 shows that the average score of every indicator in the Skills pillar of the Balkan countries lags much behind the average score of these indicators of the top 10 European countries. The biggest difference (even 33.8) is recorded in Critical thinking in teaching indicator. The next biggest difference is measured in Extent of staff training indicator (28.1), followed by Quality of vocational training indicator (27.5), and Skill set of graduates indicator (24.6). 
Only one Balkan country in only one indicator of the Skills pillar achieved a better score than the average score of the top 10 European countries. Namely, Greece records the maximum score of 100 in Pupil-to-teacher ratio in primary education indicator, which is a better score for 6.0 than the average score of the top 10 European countries. The same result in the group of the top 10 European countries is achieved by Norway.

The results of the above-mentioned analysis provide the appropriate basis for the identification of critical indicators of the Skills pillar in each Balkan country. It is the indicators that deviate from the average score of all Balkan countries. Therefore, those indicators require priority in the further development policies and improvements. The list of the critical indicators of the Skills pillar in the Balkan countries is presented in Table 3.

Table 3 - Indicators within the Skills pillar which require improvements and priority of skills development policy by the Balkan countries (2018)

\begin{tabular}{|l|l|c|}
\hline \multicolumn{1}{|c|}{ Country } & $\begin{array}{l}\text { The critical indicators which show the } \\
\text { deviations from the average score of } \\
\text { the group of the Balkan countries }\end{array}$ & $\begin{array}{c}\text { Number of } \\
\text { critical indicators }\end{array}$ \\
\hline Slovenia & $\mathrm{I}_{9}$ & 1 \\
\hline Greece & $\mathrm{I}_{1}, \mathrm{I}_{3}, \mathrm{I}_{8}$ & 3 \\
\hline Albania & $\mathrm{I}_{1}, \mathrm{I}_{9}$ & 2 \\
\hline Montenegro & $\mathrm{I}_{5}, \mathrm{I}_{7}$ & 2 \\
\hline Serbia & $\mathrm{I}_{5}, \mathrm{I}_{7}$ & 2 \\
\hline Bulgaria & $\mathrm{I}_{2}, \mathrm{I}_{3}, \mathrm{I}_{4}, \mathrm{I}_{6}, \mathrm{I}_{7}, \mathrm{I}_{9}$ & 6 \\
\hline Croatia & $\mathrm{I}_{2}, \mathrm{I}_{3}, \mathrm{I}_{4}, \mathrm{I}_{5}, \mathrm{I}_{6}, \mathrm{I}_{7}, \mathrm{I}_{8}$ & 7 \\
\hline Romania & $\mathrm{I}_{2}, \mathrm{I}_{4}, \mathrm{I}_{6}, \mathrm{I}_{7}, \mathrm{I}_{2}, \mathrm{I}_{9}$ & 6 \\
\hline North Macedonia & $\mathrm{I}_{1}, \mathrm{I}_{2}, \mathrm{I}_{3}, \mathrm{I}_{4}, \mathrm{I}_{5}, \mathrm{I}_{6}, \mathrm{I}_{7}, \mathrm{I}_{8}$ & 8 \\
\hline Bosnia and Herzegovina & $\mathrm{I}_{1}, \mathrm{I}_{2}, \mathrm{I}_{3}, \mathrm{I}_{4}, \mathrm{I}_{5}, \mathrm{I}_{6}, \mathrm{I}_{7}, \mathrm{I}_{8}, \mathrm{I}_{9}$ & 9 \\
\hline
\end{tabular}

The interpretation of the data presented in Table 3 suggests some important performances of the Balkan countries, i.e. it highlights the key indicators of the Skills pillar that need urgent improvement in the future period. Bosnia and Herzegovina is the worstpositioned country with 9 critical indicators. North Macedonia has poorer performances in 8 indicators. Croatia shows deviations in 7 indicators. These countries are followed by Romania and Bulgaria (6 critical indicators) and Greece (3 critical indicators), while Serbia, Montenegro and Albania have 2 critical indicators. Slovenia as the best-ranked country in the Balkan group has only one critical indicator.

\section{Benchmarking of skills competitiveness of the Balkan countries and top 10 European countries}

The benchmarking of skills competitiveness of the Balkan countries and top 10 European countries allow a deeper analysis of the results achieved by these groups of countries. The purpose is to specify the priorities in skills development policy for each country from the Balkan group. The methodology is based on determining the benchmark standards that are relevant to defining and implementing skills development policy, goals, and actions. 
According to Radivojević, Krstić \& Stanišić (2018) benchmark standards could be defined as target levels that each Balkan country has to accomplish in the skills development strategy at the national level. The determination of benchmark standards provides a detailed specification of priorities in development policy for each analyzed country. The criteria is founded on the urgency or time priority. Firstly, each Balkan country should upgrade the indicators in which it has poorer performances than the average score of the Balkan countries. When they accomplish the mentioned target, the goal should be the average score of the top 10 European countries. After the achievement of that goal, Balkan countries should put a higher target - the level of performance of the best countries in the group of the top 10 European countries.

Specification of the indicators within the Skills pillar according to the priority of their necessary improvement by the Balkan countries is shown in Table 4.

Table 4 - Specification of the indicators within the Skills pillar according to the priority of their necessary improvement by the Balkan countries

\begin{tabular}{|c|c|c|}
\hline Country & $\begin{array}{c}\text { The first level priority of indicators } \\
\text { - the benchmark is the average of } \\
\text { the Balkan countries }\end{array}$ & $\begin{array}{l}\text { The second level priority of indicators - } \\
\text { the benchmark is the average of the top } \\
10 \text { European countries }\end{array}$ \\
\hline Slovenia & $I_{9}$ & $I_{1}, I_{2}, I_{3}, I_{4}, I_{5}, I_{6}, I_{7}, I_{8}$ \\
\hline Greece & $I_{1}, I_{3}, I_{8}$ & $I_{2}, I_{4}, I_{5}, I_{6}, I_{7}$ \\
\hline Albania & $I_{1}, l_{9}$ & $\mathrm{I}_{2}, \mathrm{I}_{3}, \mathrm{I}_{4}, \mathrm{I}_{5}, \mathrm{I}_{6}, \mathrm{I}_{7}, \mathrm{I}_{8}$ \\
\hline Montenegro & $I_{5}, I_{7}$ & $I_{1}, I_{2}, I_{3}, I_{4}, I_{6}, I_{8}, I_{9}$ \\
\hline Serbia & $I_{5}, I_{7}$ & $I_{1}, I_{2}, I_{3}, I_{4}, I_{6}, I_{8}, I_{9}$ \\
\hline Bulgaria & $I_{2}, I_{3}, I_{4}, I_{6}, I_{7}, I_{9}$ & $I_{1}, I_{5}, I_{8}$ \\
\hline Croatia & $I_{2}, I_{3}, I_{4}, I_{5}, I_{6}, I_{7}, I_{8}$ & $l_{1}, l_{9}$ \\
\hline Romania & $I_{2}, I_{4}, I_{6}, I_{7}, I_{8}, I_{9}$ & $I_{1}, I_{3}, I_{5}$ \\
\hline North Macedonia & $I_{1}, I_{2}, I_{3}, I_{4}, I_{5}, I_{6}, I_{7}, I_{8}$ & $I_{9}$ \\
\hline $\begin{array}{l}\text { Bosnia and Herze- } \\
\text { govina }\end{array}$ & $I_{1}, I_{2}, I_{3}, I_{4}, I_{5}, I_{6}, I_{7}, I_{8}, I_{9}$ & - \\
\hline
\end{tabular}

Slovenia has only one indicator in the first level of priority, and eight indicators in the second level of priority (see Table 4). Albania, Montenegro and Serbia have two indicators in the first level of priority and seven indicators in the second level of priority. Bosnia and Herzegovina as the worst-ranked country in the Balkan group has all nine indicators in the first level of priority. A number of critical indicators of other Balkan countries in the first level of priority vary from three to eight, while a number of critical indicators in the second level of priority range from one to seven. The exception is Greece that has three critical indicators in the first level of priority and five critical indicators in the second level of priority. The indicator $l_{9}$ (Pupil-to-teacher ratio in primary education) is not stated in Table 4 in the case of Greece because this country reached the highest possible score of 100 in this indicator.

It is very indicative that the indicator $I_{7}$ (School life expectancy) is in the first level of priority (need urgent improvements) in even seven Balkan countries, while six of the top 10 European countries achieved the maximum score of 100 in this indicator (see Table 2 
and Table 4). All other indicators of the Skills pillar $\left(I_{1}, I_{2}, I_{3}, I_{4}, I_{5}, I_{6}, I_{8}\right.$ and $\left.I_{9}\right)$ are equally represented, i.e. every of these indicators is present in the first level of priority of five Balkan countries.

\section{Conclusion}

The paper has attempted to examine the current state and development potential of the selected European countries in the field of population skills. A general conclusion that can be reached in this paper is that the level of population skillscompetitiveness of the 10 Balkan countries lags significantly behind the top 10 European countries. The comparative method that has been applied in the study suggests that the average score of the Balkan countries in all nine indicators of the Skills pillar is seriously below the average score of the top 10 European countries. The largest score differences are recorded in the following indicators: Critical thinking in teaching (for 33.8), Extent of staff training (for 28.1), Quality of vocational training (for 27.5) and Skill set of graduates (for 24.6). Also, the analysis has showed that only one Balkan country in only one indicator of the Skills pillar has achieved a better score than the average score of the top 10 European countries.

The best-ranked country in the Balkan group is Slovenia (that reached the score of 73.5 and $29^{\text {th }}$ place in the world), while the worst-ranked is Bosnia and Herzegovina (that reached the score of 57.5 and $87^{\text {th }}$ place in the world). The second-ranked is Greece (70.4) and the third-ranked is Albania (68.7). The first three Balkan countries are followed by Montenegro, Serbia, Bulgaria, Croatia, Romania, North Macedonia and Bosnia and Herzegovina. It is obvious that there are great disparities even within the Balkan group when it comes to the results achieved in the skills competitiveness. More precisely, the worst-ranked country in the Balkan group (Bosnia and Herzegovina) lags behind the best-ranked country (Slovenia) for even 58 places (the difference in achieved score is even 16.0).

The authors selected the top 10 Europan countries as a benchmarking group because Europe is an absolute leader in the population skills competitiveness in global terms. According to the The Global Competitiveness Report 2018 Europe has eight countries in the world top 10. Finland records the highest skills score among 140 countries (87.9) followed by the second-ranked Switzerland (87.3) and the third-ranked Germany (85.4). The first three European countries are followed by Denmark, Netherlands, Sweden, Norway, Iceland, United Kingdom and Ireland.

The research findings of benchmarking method specify the possibilities for the improvement of performances that determine the population skills competitiveness of the Balkan countries, and also the urgency or time priority of their improvement. The analysis shows that the factors such as "school life expectancy" should have priority in the further development process of the population skills competitiveness in the Balkan countries in order to get a better place in the European region. However, formulating particular national strategies, objectives, priorities and timing of their achievement in the skills competitiveness development in the Balkan countries requires in-depth analysis of the current position of the particular Balkan country both in the Balkan group and in accordance with the top 10 European countries. 


\section{Literature}

[1] Baldacci, Emanuele, Benedict Clements, Sanjeev Gupta, and Qiang Cui. "Social Spending, Human Capital, and Growth in Developing Countries." World Development 36, no. 8, (2008): 1317-1341. doi:10.1016/j.worlddev.2007.08.003

[2] Barro, Robert and Lee Jong-Wha. "International data on educational attainment: Updates and implications."Oxford Economic Papers 3, (2001): 541-563.

[3] Bevan, Alan and Saul Estrin. "The determinants of foreign direct investment into European transition economies." Journal of Comparative Economics 32, (2004): 775-787.

[4] Bevan, Alan, Saul Estrin, and Klaus Meyer. "Foreign investment location and institutional development in transition economies." International Business Review 13, (2004): $43-64$.

[5] Bhattacharya, Mousumi, Donald Gibson, and Harold Doty. "The effects of flexibility in employee skills, employee behaviors, and human resource practices on firm performance." Journal of Management 31, (2005): 622-640.https://doi.org/10.1177/0149206304272347

[6] Bulle, Nathalie. "Comparing OECD educational models through the prism of PISA." Comparative Education 47, no. 4, (2011):503-521. http://doi.org/10.1080/03050068.2011.555117

[7] Dunning, John and Sarianna Lundan. "Institutions and the OLI paradigm of the multinational enterprise." Asia Pacific Journal of Management 25, (2008): 573-593.

[8] European Commission. Communication from the Commission to the European Parliament, the Council, the European Economic and Social Committee and the Committee of the Regions: A New Skills Agenda for Europe. Brussels, 2016.

[9] European Commission. Investment in Human Capital: Assessing the Efficiency of Public Spending on Education. Brussels, 2017.

[10] European Commission (ET2020 framework). "Education and Training: European Policy Cooperation (ET2020 framework)." Accessed April 5, 2019.

https://ec.europa.eu/education/policies/european-policy-cooperation/et2020-framework_en

[11] Green, Andy, John Preston, and Ricardo Sabates. "Education, equality and social cohesion: A distributional approach." A Journal of Comparative and International Education 33, no. 4, (2003): 453-470. http://doi.org/10.1080/0305792032000127757

[12] Herciu, Mihaela and Claudia Ogrean. "Wealth, Competitiveness, and Intellectual Capital Sources for Economic Development." Procedia Economics and Finance 27, (2015): 556-566. https://doi: 10.1016/S2212-5671(15)01033-3

[13] Jovanović, Žaklina, Slobodan Nešković and Zoran Kostić. "Ekonomija znanja i intelektualna svojina u kontekstu društvenog razvoja Srbije - studija slučaja." Vojno delo68, no. 3, (2016): 242-254.

[14] Kottaridi, Constantina, Konstantina Louloudi, and Sotiris Karkalakos. "Human capital, skills and competencies: Varying effects on inward FDI in the EU context." International Business Review 28, (2019): 375-390.https://doi.org/10.1016/j.ibusrev.2018.10.008

[15] Krstić, Bojan. Upravljanje intelektualnim kapitalom preduzeća. Niš: Ekonomski fakultet, 2014.

[16] Krstić, Bojan, Vladimir Radivojević and Tanja Stanišić. "Determinants of CEE Countries' Tourism Competitiveness: A Benchmarking Study."Management - Journal for Theory and Practice Management80, (2016): 11-22.

[17] Narula, Rajneesh and John Dunning. "Industrial development, globalization and multinational enterprises: New realities for developing countries." Oxford Development Studies 28, (2000): 141-167.

[18] Plantić, Diana. "Koncepcijom cjeloživotnog obrazovanja do veće konkurentnosti Hrvatske."Ekonomski pregled 56, no. 1-2, (2005): 93-101. 
[19] Radivojević, Vladimir, Bojan Krstić, and Tanja Stanišić. "The Role of Technological Readiness in the Global Competitiveness of Serbian Economy."Facta Universitatis, Series: Economics and Organization 15, no. 2, (2018): 111-123.

[20] Rađenović, Tamara and Bojan Krstić. "Intellectual Capital in the Theory of the Firm." Ekonomika 63, no. 4, (2017): 13-27.

[21] Savolainen, Hannu. "Responding to diversity and striving for excellence: The case of Finland." Prospects 39, no. 3, (2009): 281-292. https://doi.org/10.1007/s11125-009-9125-y

[22] Schleicher, Andreas. "Securing quality and equity in education: Lessons from PISA." Prospects 39, no. 3, (2009): 251-263. http://doi.org/10.1007/s11125-009-9126-x

[23] Suri, Tavneet, Michael Boozer, Gustav Ranis, and Frances Stewart. "Paths to Success: The Relationship Between Human Development and Economic Growth." World Development 39, no. 4, (2011): 506-522. doi:10.1016/j.worlddev.2010.08.020

[24] Sverdlova, Yulia. "Influence of Human Capital Development on Competitiveness of the EU Economy." Economic Annals XXI 2, no. 7-8, (2014): 12-15.

[25] The Organization for Economic Cooperation and Development (OECD). Lessons from PISA 2012 for the United States, strong performers and successful reformers in education. Paris: OECD Publishing, 2011.

[26] World Economic Forum. The Global Competitiveness Report. Geneva, 2018.

[27] Wright, Patric, Gary McMahan, and Abagail McWilliams. "Human Resources and Sustained Competitive Advantage: A Resource-based Perspective." Thelnternational Journal of Human Resource Management 5, no. 2, (1994): 301-326.

https://doi.org/10.1080/09585199400000020

[28] Yada, Akie, Asko Tolvanen, and Hannu Savolainen. "Teachers' attitudes and self-efficacy on implementing inclusive education in Japan and Finland: A comparative study using multigroup structural equation modeling." Teaching and Teacher Education 75, (2018): 343-355. https://doi.org/10.1016/j.tate.2018.07.011 